\title{
THE CONCEPT OF A MINI-MILL REROLLING USED RAILS AS A RAW MATERIAL
}

\author{
S. A. Levandovskiy ${ }^{1,}$ G. K. Rozhkov', A. B. Moller ${ }^{1,}$ O. N. Tulupov ${ }^{1}$ \\ ${ }^{1}$ Nosov Magnitogorsk State Technical University (Magnitogorsk, Russia) \\ E-mail: levandovskiy@mail.ru
}

\section{AUTHOR'S INFO}

S. A. Levandovskiy, Cand. Eng., Associate Prof., Materials Processing Dept.;

G. K. Rozhkov, Mag. Student., Materials Processing Dept.;

A. B. Moller, Dr. Eng., Prof., Head of Materials Processing Dept.;

O. N. Tulupov, Dr. Eng., Prof., Materials Processing Dept.

Key words:

technical specification, used rails, steel processing, secondary production, production of rebar, high-carbon steel, resource saving, minimills, micro-mills, nano-mills, world steel market, casting rolling unit, direct reduction iron.

\begin{abstract}
A B S T R AC T
There are modern conditions for the development of the metallurgical sector of the economy with some new features. The paper provides an overview of the state of modern mini-mills, their extended classification is given. As an example, an approach to formation of new and the development of existing mini-mills for the production of metal using recycled materials is given. The technology of rerolling of used rails into a square billet, reinforced bars and grinding balls is considered. The resulting production line is characterized as highly environmental friendly equipment: electric energy from a hydroelectric power station is used as the main source, secondary scrap remelting technology is not used, production wastes are minimized and secondary metallurgical raw materials are consumed.
\end{abstract}

\section{Introduction}

First of all, it is necessary to note that this article was mainly formed before the recent March 2020 events in world markets and considers the state of issues without taking these events into account.

The previous quick growth of world steel consumption and the active development of the Chinese economy help to form the new areas of intensive development of the metallurgical industry. Some economic phenomena are cyclical, and from 2008 to 2020 , we could observe a trend of slow growth in steel consumption per year (average 1-2\%) similar like in 1976-2000.

In recent years (2017-2020), with loading of production capacities about $70 \%$, a decrease in investment has been observed. The metallurgical industry, represented by both manufacturers of products and manufacturers of metallurgical equipment, is looking for ways to adapt to the situation.

Today there is a focus on production technology in the conditions of mini-mills. The fourth Danieli conference "Fourth Danieli Innovaction Meeting", held from October 3 to 5, 2017 in Italy, also considered the prospects for the active development of metallurgical mini-mills and related technologies [1,2].

\section{Mini-mills}

What is meant by the term mini-mill? A mini-mill is a metallurgical plant that occupies relatively small geographic areas, produces a small range and volume of finished products and primarily focused on sales of products in the region of location.
Some mini-mills were based on the technology of steel smelting in open-hearth furnaces, however, the modern dynamics of their development is more and more focused on electric steelmaking.

One of the first full-fledged mini-mills in the USA (Texas) was launched in 1975 by Chaparral Steel [3]. Its composition includes electric arc furnace, continuous casting machine with subsequent rolling of reinforced steel bars (rebars) up to 200,000 tons per year.

It is necessary to note that scrap metal, as a secondary raw material for steel production, contributes to decrease in product quality (in comparison with primary steel). However, modern mini-mills are focusing on small volumes and a limited assortment and produce quite goodquality products, mainly due to the wide use of casting and rolling complexes. The another USA company Nucor was one of the first to develop this market.

Looking abroad (outside of Russia), we need to pay attention to the German mini-mill Lech-Stahlwerke (Meitingen, Germany) producing rebars and precise long products for automobiles of the Mercedes and BMW brands.

Observing the mini-mill solutions market, it is necessary to mention that Danieli (Italy) has established itself as a reliable partner [2]. Several plants were launched by the company relatively recently (2016-2020): a mini-mill (with a capacity of up to 500,000 tons per year) of the Commercial Metals Co. company (Durant, Oklahoma, USA) that produces long products; a new flexible complex for the production of structural steels at the Kirov Metallurgical Plant with a capacity of 370,000 tons per year (Peskovka, Kirov region, Russia); Grupo Simec mini-mill in Mexico (Apisaco, Tlascala), with a capacity 
of 600,000 tons per year; two micro-plants of the Taybah Group (Pakistan) with a total capacity of $1 \mathrm{mln}$ tons of rolled metal per year; new metallurgical complex for annual production of up to $1 \mathrm{mln}$ tons of cast products in Ciudad Sahagun (Hidalgo, Mexico); POSCO SS-Vina mini-mill (Vietnam) with two rolling mills with a total capacity of up to $1.8 \mathrm{mln}$ tons of rolled metal per year; Aceria de Angola in Barra do Dunde (Angola) with a micro-mill with a capacity of 300,000 tons per year; Mass Global Investment company (Sulaymaniyah, Iraq) with a mini-mill with a capacity of up to 1 mln tons per year and others.

The Bervel plant was put into operation in 2015 in the Ryazan region (Russia); it produces calibrated rolled products (up to 80,000 tons per year) and high-strength fasteners (up to 27,000 tons per year).

There is a trend of diversification of activities of large metallurgical companies through using mini-mills. For example, in NMLK-Ural (Russia), these are plants in Nizhnye Sergi, Revda and Berezovskiy.

\section{Classification}

The difference in production volumes for mini-mills can reach up to 20 times (from 45,000 to $2 \mathrm{mln}$ tons per year), therefore, it possible to use the classification according to the production volume [4] (Table 1). Also are the groups of strategies for market behavior and production development are presented in this table.

According to the composition of the equipment, mini-mills can be divided into 3 groups.

1. Plants manufacturing intermediate products, such as cast billets ("truncated" plants).

2. Plants that have only equipment for manufacturing semi-finished metallurgical products to their final form without their own steel smelting (so-called semiintegrated plants).

3. Full cycle plants (both steelmaking and subsequent rolling and finishing processing).

Despite excession of capacities, a smooth growth of production continues, which is realized due to the desire of market participants to provide independently their region with products. In the context of the expansion of Chinese goods and the restrictions on imports, support for local manufacturers is increasing significantly. Now the economies of different countries are trying to support local participants in the metallurgy market.

\begin{tabular}{|c|c|l|}
\hline Table 1. Classification of plants \\
\hline Group & $\begin{array}{c}\text { Productivity, } \\
\text { thousand tons } \\
\text { per year }\end{array}$ & \multicolumn{1}{|c|}{ Development strategies } \\
\hline Nano-mills & $40-230$ & $\begin{array}{l}\text { fixing a certain market segment } \\
\text { specialization in manufacturing }\end{array}$ \\
\hline Micro-mills & $230-600$ & $\begin{array}{l}\text { fixing a certain market segment } \\
\text { specialization in manufacturing } \\
\text { cost minimization }\end{array}$ \\
\hline Mini-mills & $600-2000$ & $\begin{array}{l}\text { cost minimization } \\
\text { combination of different strategies }\end{array}$ \\
\hline
\end{tabular}

Minimizing of logistics costs is also one of the key criteria for competitiveness. Also, minimizing of delivery times increases the chances, for example, of Danieli MI.DA micro-mills (the full cycle takes only two hours) to occupy their place on the market (as an example, CMC STEEL's plant in Arizona, USA [5]).

Increase in the number of mini-mills, micro-mills and nano-mills also leads to increase in the need for scrap. Some mini-mills use pig iron and direct reduction iron (DRI). Oskol Electrometallurgical Plant (Russian Federation) operates using pellets (the main iron-containing raw material) that are obtained from the ore of the Kursk magnetic anomaly [6]. From the raw material point of view, the Russian Federation has good prospects for development of DRI production technology due to the presence of significant reserves of natural gas and iron ore. It looks promising to combine the production facilities of DRI and mini-mills in view of the availability of following opportunities: loading hot pellets into the furnace; use not only arc furnaces, but also induction furnaces; significantly denser compcting of the charge, consisting of pellets and briquettes, in the working space of the furnace.

Mini-mills strengthen the regional economy, and their mutual competition is a stimulus for technological development and improvement. As a rule, economical and market niches where opportunities and needs exist are filling quickly.

\section{Example of mini-mill development}

In recent decades, the number of industries using secondary steel as a source of raw materials has been increasing. Let's consider one of such examples - development of the technology and the formation of the technical specifications for a mini-mill that implements the technology for processing (rerolling) of used rails into grinding balls and reinforced steel bars (rebars).

This technology was developed by the specialists of the rolling group of the Materials processing department of the Nosov Magnitogorsk State Technical University (NMSTU) [7, 8]. The aim of this research was development of the technology and preparation of the technical specifications (TS).

\section{Raw materials and finished products}

Used (spent their operational life) railway rails and cast billets of square cross section are considered as raw materials for the plant (it is assumed to purchased them from a third-party manufacturer). Use of a square billet as a raw material implies use of sufficiently effective technologies (compared with already existing). However, there are no ready-made solutions in the following steps: to find the manufacturer/supplier of technology, to buy, to put into practice and to work - for using recycled rails as raw materials.

At the initial stage, the question was posed: is it possible to use rail steel for manufacture of rebars and grinding 
balls? After analyzing the regulatory documents, it was revealed that rail steel contains a large amount of manganese and carbon, therefore, the value of the carbon equivalent exceeds 1 . However, due to its similarity to steel $80 \mathrm{~S}$ (80C according to the Russian steel grade classification, the same later), rail steel can be used in manufacture of steel rebars of strength classes A600 without heat treatment. It is possible to use such rebars in reinforced concrete structures, where the rebar cage is formed by binding bars, or the option of preheating of bars before their welding (however, additional studies and experiments may be required here). As for the grinding balls - the chemical composition of rail steel is fully suitable for manufacture of this type of product.

At the next stage, possibility and practicability of developing this technology and its subsequent application were assessed. It is need to pay attention to the fact that according to statistics, over 500,000 tons of used rails in the Russian Federation and 150,000 tons of used rails in Ukraine are written off annually [9]. A list of the enterprises with similar activities has been compiled and the availability of secondary raw materials (used rails) in the required quantity has been studied (there are several companies in the Russian market supplying used rails, for example, OJS "Sila Sibiri", etc.). The technology customer had a direct agreement with the OJSC "Rossiyskiye zheleznye dorogi" (Russian Railways) on the supply of up to 150,000 tons of used rails per year at the time of the development of the technical specifications.

Similar plants manufacturing products from used rails were considered and it was concluded that use of such technology is technically possible. A study of the market condition of used rails made it possible to understand that rerolling of used rails is not only possible, but it will also be cheaper than their remelting [10-12]. Mostly $70 \%$ of the rails produced are related to two types: R65 and R50 (P65 and P50 according Russian rail normative documentation), therefore, it is possible to focus on similar sizes.

\section{Technology}

We need to pay attention to the production technology. Let's consider the technological route including the following operations: pre-treatment of used rails; heating of rails for rolling; rolling of billets for rebars and balls; rolling of rebars; rolling of grinding balls; after-rolling finishing processing; shipment and storage.

It is recommended to use only proven technological solutions during TS developing, which further reduces the risks of the project and minimizes probability of possible risks at the stages of putting into practice and mastering.

It is worth paying special attention to heating of the rails for rolling. As soon as it is planned to launch a minimill on the territory of the existing industrial area and the infrastructure formed earlier is characterized by relatively cheap and affordable electric energy (geographic location near a hydroelectric power station) that can be used for supplying this mini-mill, a preliminary conclusion can be made about the economic feasibility of using induction heating. To make a final decision, an analysis was made of the main methods of billet heating for rolling (Table 2).

As can be seen from the table 2, the choice of induction heating is technologically substantiated.

Two technological schemes of induction heating are presented for the customer's review (taking into account the required heating rate to ensure the planned production volume). Both schemes are based on the fact that inductors must be partitioned and support drive rollers should be located between them. The distance between the inductors is chosen so that the billet with a minimum length can be located at least on 3 rollers.

These schemes are characterized by the following differences:

a) the first scheme is based on heating both of the neck and the head with the rail base produce a constant current frequency of $10 \mathrm{kHz}$ to a temperature of $1250{ }^{\circ} \mathrm{C}$;

b) the second scheme is a dual-frequency heating: at first the rail is heated with a current frequency of $2.4 \mathrm{kHz}$, then the base and the neck are additionally heated with a frequency current $10 \mathrm{kHz}$, while maintaining the temperature of the rail head at the required level.

The second scheme is more expensive meaning its technological implementation and administration, however it is more efficient from the point of view of further energy consumption and allows to reduce the length of the heating inductor. This second scheme is considered as more perspective for consequent research. Current frequency parameters for the developed technology are recommended by JSC «All-Russian Scientific Research Institute of High Frequency Currents named after V. P. Vologdin» (St. Petersburg).

Next, we consider the technology of rolling (rerolling) of rails: today in the world practice several methods are used to reroll used rails into billets, which are used for the subsequent production of high-quality products. We

\begin{tabular}{|l|c|c|c|c|}
\hline \multirow{2}{*}{ Table 2. The main methods of billet heating for rolling } \\
\hline \multirow{2}{*}{ Features of heating } & \multicolumn{4}{|c|}{ Type of heating } \\
\cline { 2 - 5 } & $\begin{array}{c}\text { Gas } \\
\text { heating }\end{array}$ & $\begin{array}{c}\text { Heating } \\
\text { in resistance } \\
\text { furnaces }\end{array}$ & $\begin{array}{c}\text { Electric } \\
\text { resistance } \\
\text { heating }\end{array}$ & $\begin{array}{c}\text { Induction } \\
\text { heating }\end{array}$ \\
\hline Route & + & - & - & + \\
\hline Decarburization & - & - & + & + \\
\hline $\begin{array}{l}\text { Heating } \\
\text { of complicated } \\
\text { section shape }\end{array}$ & - & - & - & + \\
\hline Scaling & - & - & + & + \\
\hline Infrastructure & - & + & + & + \\
\hline $\begin{array}{l}\text { Environmental } \\
\text { friendliness }\end{array}$ & - & + & + & + \\
\hline $\begin{array}{l}\text { Overall assessment } \\
\text { score }\end{array}$ & 1 & 2 & 4 & 6 \\
\hline
\end{tabular}


preferred those technological processes that allow us to achieve the maximum cross-sectional area of the workpiece intended for further rolling.

After a patent search and a literature review, three methods were discovered: rerolling with surfacing, rerolling of a solid rail and rerolling in universal passes. It is rather difficult to implement these methods without separation of the rail, however, this method has found its application at the plant in Syracuse (USA) [13]. In most cases, plants use the rolling method with separation into two or three parts (Russian Federation (Tula Metal Rolling Plant), France, Ukraine, USA) [14, 15]. These technologies are patented: Russian patents: RU 2541211C2 [16] and RU 2491139 [17]. The solution of patent RU2541211C2 is separation of the rail into three parts: the neck, head and base. The solution of patent RU 2491139 is rerolling of rails with preliminary transverse separation into two parts along the neck (Fig. 1). The studied patent documents recommend heating to a temperature in the range of $1000-1200^{\circ} \mathrm{C}$, observing minimum elongations to eliminate fatigue phenomena and completely restore the original properties of steel.

Separation of the rail into two parts is more simple operation, which can also be performed in rolling stands, however, the resulting cross-section requires additional passes for a purposeful change in shape. There are also solutions for separation into 3 parts $[10,15]$, but this method is more difficult to be implemented.

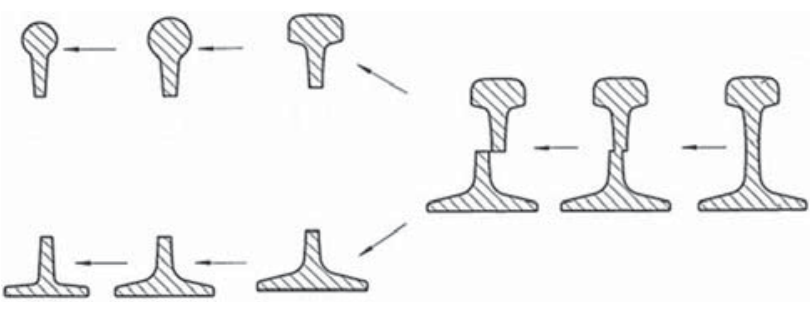

The infrastructure features of the industrial area were also taken into account during developing of this technology (Fig. 2). This site is planned as the basis for the placement of the required technological equipment.

Three options for rolling technology implementation were considered: continuous mills $700 / 500$ and 300 with separation of the rail into 2 parts; continuous mill 300 with separation of the rail into 3 parts; reversing mill 500 with a trio stand and a linear mill $300(500 / 300)$ with separation of the rail into 2 parts.

The customer has identified additional conditions to provide technological options:

- possibility to produce the final product from a square billet with a square side up to $100 \mathrm{~mm}$ and a length 3 to $6 \mathrm{~m}$;

- possibility to produce the equal angle (with flange side up to $40 \mathrm{~mm}$ ) using prepared roll pass design.

Associate professor Dmitry I. Kinzin took active part in the search of solutions for the equipment layout and the roll pass design calculation, [18].

The third option was finally selected, its schematic diagram is shown in Fig. 3.

The final chain of technological operations includes the following steps:

- preparation of rails for rolling (surface cleaning);

- cutting to a length of $4 \mathrm{~m}$ and less (cutting ends with holes are not performed);

- loading 4-meter rails onto a loading table;

- heating to a temperature of $1200-1250^{\circ} \mathrm{C}$ in an induction furnace with discharge of billets at preset speed;

- separation of the rail by rolling rolls into two parts in the middle stand of the trio line of the 500 mill using separating passes;

- rolling of the part of the rail with the head (after separation) to a round cross section with $20-50 \mathrm{~mm}$ diameter on the third stand of the trio line of the 500 mill, then its cutting into measured lengths and loaded into a piling bin (rods are used as billets for a ball rolling mill);

Fig. 1. Explanation of Patent RU 2491139

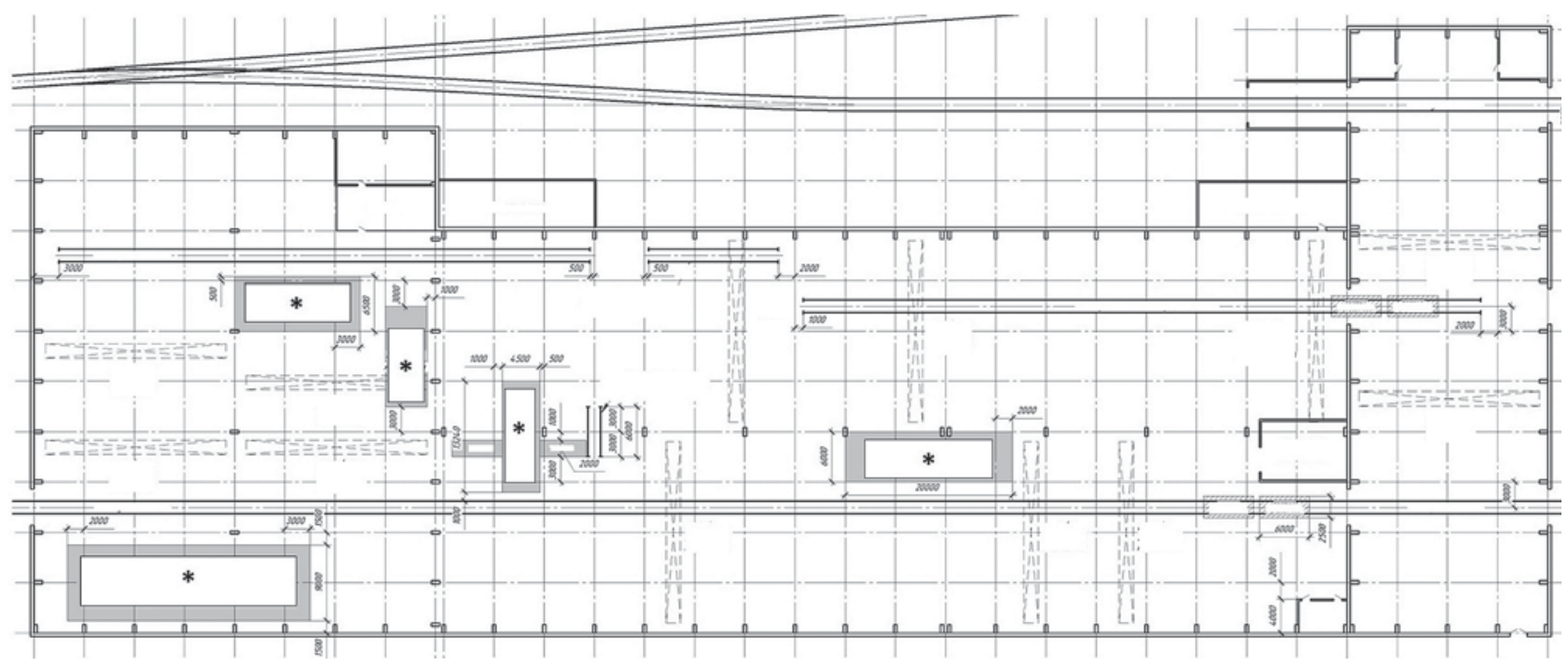

Fig. 2. Scheme of an industrial area for construction of the plant (* - existing equipment) 


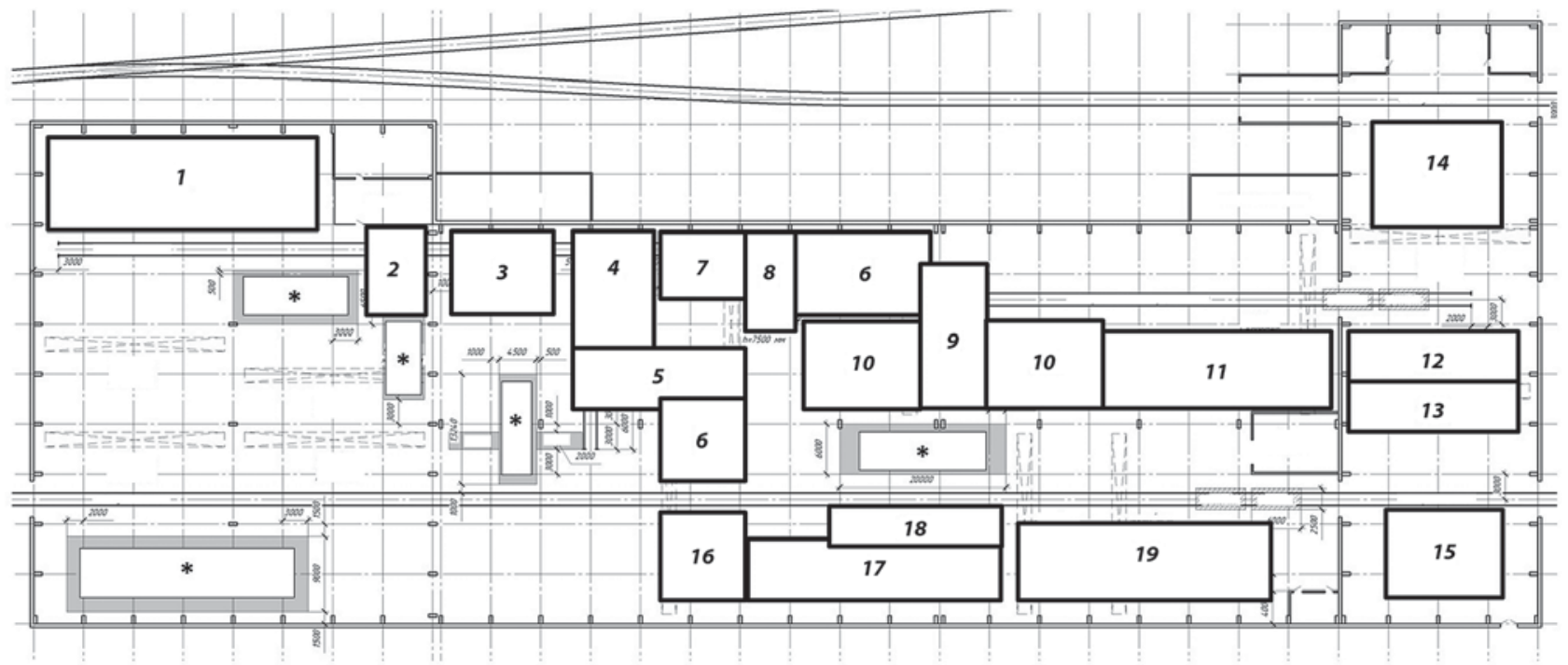

Fig. 3. Schematic diagram of production:

1 - straightening and scarfing area for rails; 2 - loading table; 3 - inductors; 4 - transfer table; 5 - transfer rolling table; 6 - transfer table; 7 - tilting table; 8 - Trio mill line; $9-$ Duo mill line; 10 - loop area; 11 - cooling bed; 12 - straightening machine and cold cutting shears; 13 - piling bin; 14 - storehouse of finished products; 15 - storehouse of balls; 16 - storehouse of billets for ball rolling mill; 17 - machine room of ball rolling mill; 18 - cutting and straightening area for billets; 19 - ball rolling mill; * — existing equipment

- rolling of the part of the rail with the base in the first stand of the trio line of the 500 mill and then in the linear mill 300;

- rerolling of the part of round billets for a ball rolling mill into rebars after reheating, reloading of billets after cooling with a crane onto a loading table and their rolling in a trio line and a linear group;

- cutting of the metal after rolling cut on flying shears to the length of the cooling bed, cooled, straightened and cut to measured lengths;

- rolling of round billets with $20-50 \mathrm{~mm}$ diameter on specialized ball-rolling mill (BRM) (the technology was selected for BRM 20-60).

About 40,000-60,000 tons per year of used rails will be reheated and rerolled. The required productivity of the induction furnace should be 170,000-190,000 tons per year. The planned capacity of a ball-rolling mill makes from 9,500-36,000 tons per year (depending on the rolled shape size from 20 to $60 \mathrm{~mm}$ ).

It is recommended at the initial stage to limit the use of hand work to perform turning operations, transfer the metal between stands and the metal feed to the roll gap. It will be possible to carry out step-by-step mechanization and automation of these processes during mastering the rolling technology.

The technical specification of the work indicates the need to use used rails of category R1-R3 as well as R4 rails that are unsuitable for stacking in the railway track (P1-P3 and $\mathrm{P} 4$ according Russian rail normative documentation) as the billets (except a.m. potential usage of square billets delivered by the third side). All these rail categories are related to the rail types R65 (P65) with 90\% probability and R50, R75 (P50, P75) with $10 \%$ probability. These rails have length $12.5 \mathrm{~m}$ and are prepared for rerolling by autogenous cutting into workpieces 4-6 $\mathrm{m}$ long (taking into account the possibility of rational use of sections with a drilled holes on the rail wall).

The rolling mill area consists of the Trio line mill and the Duo line mill.

The Trio line mill includes three trio stands. They are characterized by maximum distance between roll axes $530 \mathrm{~mm}$, maximum roll diameter $500 \mathrm{~mm}$, roll barrel length $900 \mathrm{~mm}$, roll speed $110 \mathrm{rpm}$, drive power $1500 \mathrm{~kW}$. The main line of the Trio mill stands also includes spindles, a gear stand, a gearbox, a flywheel and an electric drive.

The linear Duo group consists of 7 stands. Their operating parameters are the following: maximum distance between roll axes $360 \mathrm{~mm}$, maximum roll diameter $400 \mathrm{~mm}$, roll barrel length $500 \mathrm{~mm}$, roll speed $200 \mathrm{rpm}$, drive power $1500 \mathrm{~kW}$. It is recommended to the customer to choose Danieli company as a supplier of equipment for rolling mills (Trio and Duo stands), since Italian production lines are usually cheaper than German analogues from SMS group. However, it is necessary to request specific commercial offers for the developed technology from both companies.

The features of induction heating before rerolling of rails are presented below.

1. Heating of all rail sizes at a frequency of $2.4 \mathrm{kHz}$ with heating of the necks and bases at a frequency of $10 \mathrm{kHz}$. Use two lines of 5 modules of $500 \mathrm{~kW}, 2.4 \mathrm{kHz}$ and three modules of $250 \mathrm{~kW}$, with a frequency of $10 \mathrm{kHz}$ in the output part. The length of the heating part is $12 \mathrm{~m}$.

2. Heating of square billets: 6 modules of $500 \mathrm{~kW}$ are installed in the line, with a frequency of $1 \mathrm{kHz}$ with a common automatic control and protection system. The length of the heating part is $8 \mathrm{~m}$. 
3. Induction heating before rolling of balls is carried out at an operating frequency of $4 \mathrm{kHz}$ at a power of $2000 \mathrm{~kW}$ (4 units of $500 \mathrm{~kW}$ each).

Technological procedures have been developed to implement the proposed technology. These developments include roll pass design for whole required grade and dimension range (rebars with a nominal diameter of $10-32 \mathrm{~mm}$, billets for grinding balls with a diameter of $20-60 \mathrm{~mm}$, grinding balls with a diameter of $20-60 \mathrm{~mm}$. Also the fund of working time and productivity are calculated (production volume of $80,000-130,000$ tons per year with a normative fund of working time of 7,200 hours per year), automation and metrological support systems is described, the planned steps of commissioning and environmental assessment of the technology and equipment are presented.

TS contains all required information about technical and technological solutions for the above-mentioned production facilities, including structural layout solutions, technological scheme, basic equipment parameters, roll pass design, automation requirements and other issues sufficient to form the technological part of the "Investment Justification". The calculation of capital costs, profitability, cost of production, capital intensity (and other economic indicators) in the framework of work on the TS creation were not carried out by employees of NMSTU, as this work was carried out by other participants in the customer's project.

\section{Conclusion}

It should be noted that the existing technologies of mini-mills are developing and adapting to the needs (local provision of the region with metal rolled products) and opportunities (using a secondary raw material base) of the economy. The article presents a concept that is preferable from the point of view of environmental friendliness, since electric current from hydroelectric power plants is used as the main source of energy, production wastes is minimized and secondary metallurgical raw materials are consumed, while the technology of secondary remelting of scrap is not used.

\section{REFERENCE}

1. Danieli Innovaction meeting. Strategies for managing successfully during "new normal". Danieli News. 2018. January. No. 177. pp. 6-7.

2. Danieli undisputed leadership in mini-mill technology. Danieli News. 2016. March. No. 173. pp. 18-37.
3. Lincoln R. E., Wilson, P. B., Hunt H. D. Chaparral steel. 15 years of innovative steelmaking. Ironmaking and Steelmaking. 1990. Vol. 17, Iss. 3. pp 193-196.

4. Smirnov A. N., Safonov V. M., Dorokhova L. V., Tsuprin A. Yu. Metallurgical mini-mills. Donetsk : Nord-Press. 2005. Vol. 1. 2005. 469 p.

5. Alzetta F., Großmann E., Schröder J. Latest breakthrough technologies in industrial operation. Stahl und Eisen. 2011. Vol. 131. No. 11. pp. 92-108

6. Soifer V. M. Use of DRI products in electric steelmaking furnaces. Vestnik Kharkovskogo natsionalnogo avtomobilno-dorozhnogo universiteta. 2006. No. 33. pp. 32-34.

7. Rozhkov G. K., Levandovskiy S. A., Sarancha S. Yu., Moller A. B., Kinzin D. I., Tulupov O. N. Development of upto-date resource-saving production technology for reinforced bars and grinding balls. Modelirovanie i razvitie protsessov OMD. 2019. No. 3(30). pp. 18-22.

8. Rozhkov G. K., Levandovskiy S. A. Development of the minimills concept for manufacture of rolled steel products. Kalibrovochnoe byuro. 2018. No 12. pp. 5-9.

9. Rail market review in Russia and other CIS countries. The report of "Infomine" research group. Moscow. 2015. 125 p.

10. Bakhtiniov Yu. B. On expedience of rerolling of worn rails in sections. Proizvodstvo prokata. 2000. No. 7. pp. 2-4.

11. Umanskiy A. A., Dorofeev V. V., Golovatenko A. V., Dobryanskiy A. V. Development and improvement of modes of rolling of asymmetric rail profiles on the modern universal rolling mill. Chernye metally. 2018. No. 10. pp. 38-42.

12. Golovatenko A. V., Dorofeev V. V., Dobryanskiy A. V., Pervushin D. E.. Development of energy efficient rolling technology for long-length rails at the universal rail and structural mill of JSC "EVRAZ ZSMK". Chernye metally. 2019. No. 6. pp. 29-34.

13. MI.DA. ESC-Energy Saving Compact plants [Web resource]. URL: https://www.danieli.com/en/products/processes-technologies/product-lines/mi-da-esc-energy-saving-compactplants_26_188.htm (access date: 13.04.2020).

14. Smirnov V. K., Shilov V. A., Mikhailenko A. M. Et al. Processing technology of railroad rails to rolled sections. Stal. 1995. No. 2. pp. 46-48.

15. Badyuk S. I., Leshchenko A. I. Production of rolled sections from worn railroad rails. Obrabotka metallov davleniem. 2010. No. 4. pp. 162-167.

16. RF Patent RU 2541211 C2, MПK B21B1/08. Matlashov A. M. The method of fabrication of rolled sections from rail fragments. Byulleten izobreteniy. 2014. No. 10.

17. RF Patent RU 2491139 MПК B21B1/08. Volshonok I. Z., Traino A. I., Ivanov D. M., Rusakov A. D., Ryzhik M. P. The method of shape rolled sections production. Declarant and Patent-owner: National University of Science and Technology "MISiS". Byulleten izobreteniy. 2012. No. 24.

18. Levandovsky S. A., Tulupov O. N., Moller A. B., Kinzin D. I. Improvement of the slitting process for rebar rolling to increase the material yield and rolling mill 370 utilization at PJSC "MMK". CIS Iron and Steel Review. 2018. Vol. 15. pp. 18-23.

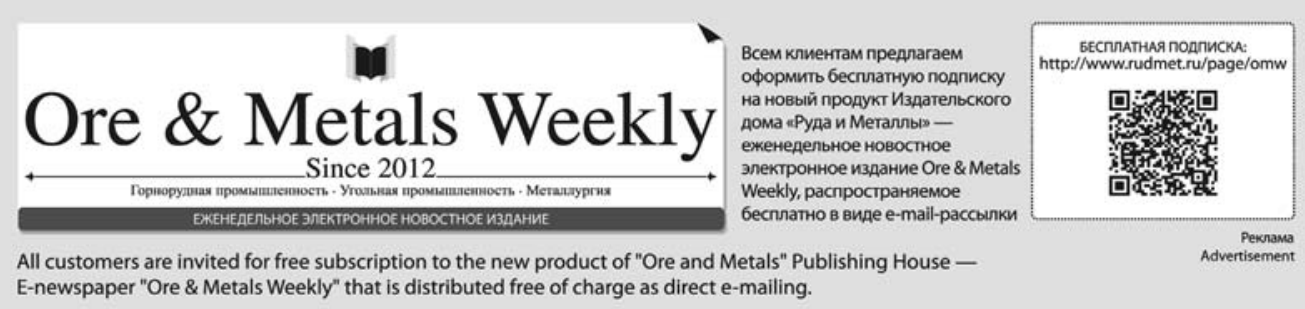

